\title{
Higher Education in Nepal
}

\author{
Jitendra Prasad Upadhyay (Ph D) \\ Associate Professor,Nepal Commerce Campus
}

\begin{abstract}
Background - Higher education is very important for the development of the nation. It is recognized today as a capital investment and is of paramount importance for economic and social development of the country. Quality higher education is a source of great potential for the socio economic and cultural development of the country. The nation can be transformed into a developed nation within the life time of a single generation

Purpose - The purpose of the study is to study about the effectiveness of higher education of Nepal
\end{abstract}

Methodology - Due to the specific nature of the research objectives, descriptive cum analytical research design has been used.

Findings - Higher Education in Nepal is satisfactory and every stakeholders of the Nepal have been satisfied with the performance of the higher education of Nepal.

Practical Implications - This study has widely tested the effectiveness of the higher education in Nepal. It helps to improve the quality of higher education in Nepal

Keywords - Higher Education

Paper Type - Research Paper

\section{Background}

Higher education is the sign of economic and social development in the country. It helps in preserving and developing the historical and cultural heritage of the nation. Similarly it helps in producing competent manpower in the global context and it encourages and promotes research in the different areas of education.

The history of higher education development in the country is very short but it has been rapid since the establishment of Democracy in 1950s. In Nepal, modern higher education began with the establishment of Tri Chandra College, the first institution of higher education, in 1919 (first affiliated with Calcutta University, then with Patna University of India). Favorable environment for expansion of higher education was created with the political change in 1951, when the Rana rule was overthrown. Higher Education (in T.C. College) was available for those who passed SLC examination. The fees were quite low. There was access for all, who sought to get admission. Students who did Bachelor level study had to go to India for Master level study.

Prior to the establishment of the Tribhuvan University, some classes were conducted in Kathmandu under the prescribed courses of Patna University. The University conducted examinations with their own question papers and conferred 
Degree to succeeded students.

The TU was established in Kathmandu in 1959, since then, the university has taken the sole responsibility of providing higher education in the country. The university started teaching post graduate courses at different constituents and affiliated campuses. The higher education study courses were provided in different areas of Humanities, Agriculture, Forestry, Sciences, Management, Medicines and Engineering etc. Now, Nepal has different universities offering different courses e.g. Nepal Sanskrit University offers the study of Sanskrit to a very restricted group and Kathmandu University, Pokhara University and Purbanchal University, private sector universities offers the study of Humanities, Sciences, Management, Medical and Engineering.

Though Nepal has achieved remarkable progress in higher education development since early 1970s when the Government started to implement the National Education System Plan (NESP). Five critical issues in the current higher education development in Nepal are:

a. the over rapid expansion of enrolment

b. the under-financing of the higher education system

c. the low level of managerial effectiveness

d. the irrational structure of the system

e. quality erosion.

\subsection{Brief Description of the Universities}

a. Tribhuvan University (TU)

Tribhuvan University is the largest university of the Nepal. The TU was established at Kathmandu in 1959. Since then, the TU has taken the sole responsibility of providing higher education in the country. It has five Institutes (Engineering, Agriculture and Animal Science, Medicine, Forestry and Science and Technology), and four Faculties (Humanities and Social Sciences, Management, Education and Law). The university has 60 constituent campuses (directly managed and operated by the University) and more than 1,000 affiliated campuses.

\section{b. Kathmandu University (KU)}

Kathmandu University was established on 2048 with its main campus in Dhulikhel (Kavre District). It is an autonomous, not-for-profit, non - government institution dedicated to maintain high standards of academic excellence. It is committed to develop leaders in professional areas through quality education It has six schools: Sciences, Engineering, Management, Medical Science, Education and Arts. Education and Management courses are conducted in Lalitpur. Science, Medicine and Engineering courses are run in Dhulikhel.

\section{c. Pokhara University $(P U)$}

Pokhara University is located at Khudi, Dhungepatan, Pokhara Lekhnath Metropolitan City of Kaski district, thirteen (13) kilometers east from Pokhara city. It was established on 1997 under Pokhara University Act, 1997. The main programs offered by this university are Medical, Engineering, Management, 
Science \& Technology, Humanities \& Social Science and Health Science.

\section{d. Purbanchal University}

The establishment of Purbanchal University in 1993 was visualized as an extraordinary endeavor by the Government of Nepal to create an academic centre of excellence in the Eastern Development Region of Nepal. Its prime role was outlined to act as a catalytic agent for the promotion of socio-economic transformation in Nepal through quality education appropriate for quality life and sustainable future. The main programs offered in this university are Management, Arts, Education, Law, Science \& Technology, Engineering and Medical \& Allied Science

\section{e. $\quad$ Nepal Sanskrit University}

Nepal Sanskrit University (formerly Mahendra Sanskrit University), established in December 1986, has its central office at Beljhundiin Dang district of mid western Development Region, Nepal, which is $13 \mathrm{~km}$ from the headquarters, Ghorahi. The university offers Intermediate (Uttar Madhyama), Bachelor (Shastri), Bachelor of Education, Masters (Acharya) and Doctoral courses in classical and modern subjects. It offers intermediate in Ayurveda and condensed courses for Ayurvedacharya. The university was established for preserving and promoting Sanskrit education in Nepalese society.

\subsection{Objectives of Higher Education}

Higher education is recognized today as a capital investment and is of paramount importance for economic and social development of the country. The main objectives of higher education are as follows:

- To impart higher education to the people as per the need of the country.

- To preserve and develop the historical and cultural heritage of the nation.

- To produce man power competent enough in the global context.

\subsection{Challenges in Higher Education in Nepal}

Higher education in Nepal have faced several challenges in the shape of various economic, social, political, and moral changes, and its future depends on the response made by its people to these challenges. The problems plaguing the educational system of Nepal are multidimensional like population explosion, lack of resources, non participation of the private sector, scarcity of qualified man power, inconsistency in the policies of various regimes, political instability, inefficient educational management system, wastage of resources, and poor implementation of policies and program etc. The major challenges in higher education in Nepal are as below:

\section{a. Quantity and Quality:}

After the restoration of democracy, the number of educational institutes and number of students in colleges and universities have been increased rapidly. But the maintenance of the quality of the educations is challenging because the quality of education is poor in Nepal. 
b. $\quad$ Lack of Infrastructure and Other Facilities:

Lack of physical and educational facilities in Nepalese education institutions is another major challenge of higher education in Nepal. The salary, financial rewards and benefits for the faculty and staff are very low according to the rising cost of living in Nepal. Beside, infrastructure facilities are also not sufficient, there are not enough well equipped library, office rooms, toilets, administration offices, classrooms, engineering, science, and other laboratories for the growing student body and faculty members.

\section{c. Competent Teachers:}

Most of teachers have limited knowledge about subject matter they taught and many of them have no clear idea about the subject. They have limited knowledge of research work. Many present faculty members are teaching courses which are not their own specialization. Many faculty members in most of universities are just master degree holders with little or no practical knowledge and higher education experiences.

\section{d. Political Interference:}

The major problem surrounding higher education is the political involvement of teachers, staff and students. It is big challenges that have been seen higher education in Nepal. Most of the teachers and staff are appointed by political influence.

e. $\quad$ Poor Administrative Work:

It is found that despite the resources available for university expansion; they have not been able to obtain the best possible results. This is due to lack of proper administration and political influence in administrations.

\section{f. Teacher/Students Ratio:}

The current size of present faculty is very small according to the general international standard. The teacher/student ratio is very small even according to many third world countries standards.

\section{g. Educational Policies:}

Educational polices include the subject matter and methods of instruction, facilities and support for the research work of faculty members and students, standards for admission of students, academic calendar etc. Timely revision of such policies is very challenging work.

\section{h. Courses and Curriculum:}

It is very difficult to design the courses and curriculum in accordance with the standard of higher education of the present day. It is seen that so many important and modern courses required for higher education are not taught at all. The curriculums are not written in detail and are left to the professors' personal likes, dislikes, interests or experience. 
i. $\quad$ Budgeting and Financing:

Another challenge for higher education is lack of budgeting and financing for expanding infrastructure and improving the quality of higher education in Nepal. The conventional system of an annual budget system should be improved by adopting new budgeting system because conventional budgeting is most confusing and least understood.

\section{Objectives of the Study}

The main objective of the study is to examine the present scenario of higher education in Nepal. Other specific objectives are

- To assess the effectiveness of higher education in Nepal from the faculties perspectives

- To assess the effectiveness of higher education in Nepal from the students perspectives

- To assess the effectiveness of higher education in Nepal from the employer perspectives

\section{Limitations of the Study}

The following are the main limitations of this study:

- This study has evaluated the effectiveness of Higher Education from the perspectives of only three stakeholders i.e. faculties, students and employers

- Only five universities have been taken as samples out of nine universities including three recognized universities for taking opinions from faculties and students

- Only five sectors of industry (banking, education, medical, engineering and miscellaneous) have been selected for taking opinions of employers. From each sectors two organizations have selected.

- Only six institutes have been selected from Tribhuvan Universities one each from Education and Engineering institutes and two each from management and medical institutions.

- Only four institutes have been selected from Kathmandu, Pokhara and Purbanchal Universities one each from Education, Engineering, management and medical institutions.

- Only one institute has been selected from Nepal Sanskrit Universities

- Only sixty respondents have been selected from gender wise and age wise for the studies

\section{Methodology Used}

This study has followed both descriptive and analytical approach of research. Both primary and secondary data have been used for the study. A questionnaire survey was conducted for getting the answer of research questions. The questionnaire survey includes 12 questions. Questionnaires were distributed to 60 genuine respondents of different universities and organizations. Out of 60 , respondents 4 faculties \& 4 graduate students from each university except Tribhuvan University (6 faculties and 6 graduates) and Nepal Sanskrit University (2 faculties and 2 students) and 2 employers 
from each organization have been selected. In order to increase the reliability and number of responses, personal visits to each and every respondent were made to distribute and collect the questionnaire.

The primary data has been analyzed using different statistical tools, like means, standard deviation; and coefficient of variance. Five scale Likert Scale has been used for analysis on which 1 represented worst and 5 represented best.

There are total of twelve universities i.e. nine universities and three recognized universities in Nepal, which constitutes the population of the study. For this study, only five universities i.e. Tribhuvan University (TU), Kathmandu University (KU), Pokhara University (PU), Purbanchal University (PRU) and Nepal Sanskrit University (NSU), have been selected as sample universities. Similarly, 2 organizations from each sector have been selected as sample organization (from banking sector Nepal Rastra Bank \& Rastriya Banijya Bank, from education sector Ace Institute of Management \& Everest College, from medical sectors Grandy Hospital \& Teaching Hospital, form engineering sectors Kantipur Engineering College \& Nepal Engineering Association and from miscellaneous sectors Citizen Investment Trust \& C G Group). Selection of sample is based on judgmental basis.

Cronbach's Alpha test has been done to test the reliability of data. Each and every variable have been tested and it was found that every variable reliability test was above $87 \%$.

\subsection{Respondent's Profile}

In this section, characteristics of respondents have been presented first gender wise and then age wise.

a. Gender Wise Respondents

\begin{tabular}{lccccc}
\hline Name of the Universities/Organizations & Male (No.) & $\%$ & Female (No.) & $\%$ & Total \\
\hline Tribhuvan University & 7 & 11.67 & 5 & 8.33 & 12 \\
Kathmandu University & 5 & 8.33 & 3 & 5 & 8 \\
Pokhara University & 6 & 10 & 2 & 3.33 & 8 \\
Pubanchal University & 6 & 10 & 2 & 3.33 & 8 \\
Nepal Sanskrit University & 3 & 5 & 1 & 1.67 & 4 \\
Banking Sectors & 2 & 3.33 & 2 & 3.33 & 4 \\
Education Sectors & 3 & 5 & 1 & 1.67 & 4 \\
Medical Sectors & 2 & 3.33 & 2 & 3.33 & 4 \\
Engineering Sectors & 2 & 3.33 & 2 & 3.33 & 4 \\
Miscellaneous Sectors & 2 & 3.33 & 2 & 3.33 & 4 \\
\hline Total & 38 & 63.33 & 22 & 36.67 & 60 \\
\hline
\end{tabular}

Majority of respondents were males i.e. $63.33 \%$. But female respondents were also satisfactory i.e. $36.67 \%$ or in number 22 out of 60 .

The highest number of male and female respondents was in TU i.e. 7 and 5 in number respectively. Similarly lowest number of male respondents was in Banking, Medical, Engineering and Miscellaneous sectors and female were in NSU and Education sector i.e. is 2 and 1 in number respectively. 
The reason behind low number of female respondents is that all institutions have high number of male employee,

b. $\quad$ Age Wise Respondents

\begin{tabular}{|c|c|c|c|c|c|c|c|}
\hline Name of the Universities/Organizations & $20-35$ & $\%$ & $35-50$ & $\%$ & above 50 & $\%$ & Total \\
\hline Tribhuvan University & 5 & 8.33 & 4 & 6.67 & 3 & 5 & 12 \\
\hline Kathmandu University & 3 & 5 & 3 & 5 & 2 & 3.33 & 8 \\
\hline Pokhara University & 4 & 6.67 & 2 & 3.33 & 2 & 3.33 & 8 \\
\hline Pubanchal University & 4 & 6.67 & 2 & 3.33 & 2 & 3.33 & 8 \\
\hline Nepal Sanskrit University & 1 & 1.67 & 2 & 3.33 & 1 & 1.67 & 4 \\
\hline Banking Sectors & & & 2 & 3.33 & 2 & 3.33 & 4 \\
\hline Education Sectors & 1 & 1.67 & 2 & 3.33 & 1 & 1.67 & 4 \\
\hline Medical Sectors & & & 2 & 3.33 & 2 & 3.33 & 4 \\
\hline Engineering Sectors & & & 2 & 3.33 & 2 & 3.33 & 4 \\
\hline Miscellaneous Sectors & & & 1 & 1.67 & 3 & 5 & 4 \\
\hline Total & 18 & 30 & 22 & 36.67 & 20 & 33.33 & 60 \\
\hline
\end{tabular}

Majority of respondents were found to be between 35 to 50 years group i.e. $36.67 \%$. Very few respondents fall in the category of $20-35$ years group i.e. 18 . Respondents in category above 50 years group were 20 i.e. $33.33 \%$.

\section{Analysis and Finding of Data}

Education sector is estimated to contribute 7.23 percent to GDP in fiscal year 2014/15. GVA of this sector, which rose by 7.04 percent in FY 2015/16, is estimated to rise by 4.21 in current fiscal year. Despite increment in GVA of private educational institutions due to low intermediate consumption and increased income, GVA of the education sector saw a normal growth as the number of students in community schools did not increase significantly.

\subsection{Higher Education System in Nepal}

The higher education system of the country comprises of nine universities, three recognize universities (B. P. Koirala Institute of health Science, National Academy of Medical Sciences and Patan Academy of Health Science) have been producing high standard human resources by conducting higher education teaching learning programs in different subjects. Act has been passed for the establishment of Open University and which was already established in the current fiscal year.

The number of students studying in the colleges under various universities running across the country has reached to 441,461 by fiscal year 2015/16 with increment of 17.8 percent as compared to previous fiscal year. Such number during fiscal year $2014 / 15$ was 374,647 . Due to high fluctuation in the number of students studying in Tribhuwan University (TU), massive change is observed in total number of students since fiscal year 2012/13. The number of students in Tribhuwan University which was 604,437 in fiscal year 2012/13 reached to 405,341 in fiscal year 2013/14 recording 32.94 percent reduction. Similarly, the number of students in TU which stood at 297,990 in 
fiscal year 2014/15 increased to 360,254 in fiscal year 2015/16.

5.1.1 Total Number of Campuses in different Universities of Nepal

\begin{tabular}{lccc}
\hline Name of the Universities & Constituent & Affiliated & Total \\
\hline Tribhuvan University & 60 & 1053 & 1113 \\
Kathmandu University & 6 & 15 & 21 \\
Purbanchal University & 5 & 126 & 131 \\
Nepal Sanskrit University & 14 & 11 & 25 \\
Pokhara University & 5 & 58 & 63 \\
Lumbini Boudha University & 1 & 5 & 6 \\
Agriculture and Forestry Science University & 1 & - & 1 \\
Far Western University & 1 & - & 1 \\
Mid Western University & 1 & - & 1 \\
B P Koirala Institute of Health Sciences & 1 & - & 1 \\
National Academy of Medical Sciences & 1 & - & 1 \\
Patan Academy of Health Sciences & 1 & - & 1 \\
\hline Total & 97 & 1268 & 1365 \\
\hline
\end{tabular}

Source: Economic Survey (2015/16)

Among different Universities almost 81 percent of the total number of campuses have been in Tribhuvan University alone which is followed by Purbanchal University i.e.131 and Pokhara University i.e.63.

5.1.2 Total Number of Students Enrollment in different Universities of Nepal

\begin{tabular}{|c|c|c|c|c|c|c|}
\hline Name of the Universities & $2013 / 14$ & $\%$ & $2014 / 15$ & $\%$ & $2015 / 16 * *$ & $\%$ \\
\hline Tribhuvan University & 405,341 & 84.29 & 298,990 & 79.81 & 360254 & 81.60 \\
\hline Kathmandu University & 14,709 & 3.06 & 15.852 & 4.23 & 16,734 & 3.79 \\
\hline Purbanchal University & 24,441 & 5.08 & 23,539 & 6.28 & 25,233 & 5.72 \\
\hline Nepal Sanskrit University & 3,862 & 0.80 & 3,412 & 0.91 & 3,533 & 0.80 \\
\hline Pokhara University & 25,290 & 5.26 & 25,531 & 6.81 & 27,111 & 6.14 \\
\hline Lumbini Boudha University & 256 & 0.05 & 215 & 0.06 & 276 & 0.06 \\
\hline $\begin{array}{l}\text { Agriculture \& Forestry Science } \\
\text { University }\end{array}$ & 446 & 0.09 & 1,565 & 0.42 & 1,785 & 0.40 \\
\hline Far Western University & 2,461 & 0.51 & 1,829 & 0.49 & 1,941 & 0.44 \\
\hline Mid Western University & 1,944 & 0.40 & 2,522 & 0.67 & 2,623 & 0.59 \\
\hline $\begin{array}{l}\text { B P Koirala Institute of Health } \\
\text { Sciences }\end{array}$ & 1,435 & 0.29 & 351 & 0.09 & 950 & 0.22 \\
\hline $\begin{array}{l}\text { National Academy of Medical } \\
\text { Sciences }\end{array}$ & 465 & 0.09 & 546 & 0.15 & 654 & 0.15 \\
\hline Patan Academy of Health Sciences & 241 & 0.05 & 295 & 0.08 & 367 & 0.08 \\
\hline Total & 480,891 & 100 & 374,647 & 100 & 441,461 & 100 \\
\hline
\end{tabular}

Source: Economic Survey (2015/16) and ** Personal Interview 
Statistics have shown that out of total students studying in different universities almost 80 percent of the total number of students was studying in Tribhuvan University alone which is followed by Pokhara University, Purbanchal University and Kathmandu University.

5.1.3 Total Number of Students Production details in different Universities of Nepal for F. Y. 2014/15

\begin{tabular}{lccc}
\hline \multicolumn{1}{c}{ Name of the Universities } & Enrollment & Production & $\%$ \\
\hline Tribhuvan University & 298,990 & 62,182 & 20.80 \\
Kathmandu University & 15.852 & 2,284 & 14.41 \\
Purbanchal University & 23,539 & 4,644 & 19.73 \\
Nepal Sanskrit University & 3,412 & 1,516 & 44.43 \\
Pokhara University & 25,531 & 3,951 & 15.48 \\
Lumbini Boudha University & 215 & 6 & 2.80 \\
\hline Total & 367,539 & 74,583 & 20.29
\end{tabular}

Source: Economic Survey (2015/16)

Only about 20 percent students were passed out during F.Y. 2014/15. Highest number of passed out students have been in Nepal Sanskrit University i.e. about 44 percent followed by Tribhuvan University and Purbanchal University about 20 percent. Only about 3 percent students have been passed out in Lumbini Boudha University.

\subsection{Analysis of the Effectiveness of Higher Education in Nepal from Faculties, Students and Employer Perspectives}

5.2.1 Analysis of the Effectiveness of Higher Education in Nepal from Faculties Perspectives

To what extents are the faculties of the universities are motivated and satisfied by the higher education in Nepal? This question is very important for assessing the effectiveness of higher education in Nepal. In this regard five questions have been asked to the faculties i.e. "How much are they satisfied" a. with the performance of the students (SP), b. with the subjects and contents of the subject teaching in the universities (SC) c. with the evaluation system (ES) d. with the infrastructure and policies of the university (IP) and e. How much they are motivated in their professions (M).

\begin{tabular}{lccccccccc}
\hline Name of the Banks & SP & SC & ES & IP & M & Total & Mean & S. D. & C. V. \\
\hline Tribhuvan University & 3.2 & 3.0 & 2.8 & 3.6 & 3.4 & 16 & 3.2 & 0.32 & 10 \\
Kathmandu University & 3.6 & 3.7 & 3.4 & 3.5 & 3.3 & 17.5 & 3.5 & 0.16 & 4.57 \\
Purbanchal University & 2.9 & 3.3 & 3.0 & 2.8 & 2.8 & 14.8 & 2.96 & 0.21 & 7.09 \\
Nepal Sanskrit University & 3.8 & 3.6 & 3.6 & 3.0 & 3.3 & 17.3 & 3.46 & 0.31 & 8.96 \\
Pokhara University & 3.0 & 3.3 & 3.1 & 2.9 & 2.8 & 15.1 & 3.02 & 0.19 & 6.29 \\
\hline
\end{tabular}

Effectiveness of Higher Education from Faculties Perspectives has ranged 
between $2.96(\mathrm{PbU})$ and $3.50(\mathrm{KU})$. All most all the faculties of the universities seem to have satisfied with the performance of their students, with the contents of the subjects, with the evaluation system and infrastructure \& the policies of the universities. This has been supported by the values more than 3 in all universities except in Purbanchal and Pokhara Universities in which values have been below 3 in case of contents of the subjects and evaluation system. All the faculties have been motivated and satisfied on their job except in Pokhara and Purbanchal Universities.

The overall effectiveness of higher education in Nepal from faculties' perspectives has been satisfactory. In all the universities, the value of standard deviation has been below 1 and coefficient of variation has been $4.57 \%$ to $10 \%$. This clearly indicates the representative nature of the mean calculated.

\subsubsection{Analysis of the Effectiveness of Higher Education in Nepal from Students} Perspectives

How happy or satisfied the students are the education provided by the universities is another important issue. In other word, to what extents are the students of the universities are satisfied by the higher education in Nepal? In this regard four questions have been asked to the students i.e. "How much they are satisfied" a. with the overall teaching faculties (SF), b. with the courses and contents of the course teaching in the universities (CC) c. with the evaluation system (ES1) and d. with the infrastructure and policies of the university (IP1)

\begin{tabular}{lcccccccc}
\hline Name of the Banks & SF & CC & ES1 & IP1 & Total & Mean & S. D. & C. V. \\
\hline Tribhuvan University & 3.6 & 3.2 & 3.0 & 3.6 & 13.4 & 3.35 & 0.30 & 8.96 \\
Kathmandu University & 3.4 & 3.4 & 3.3 & 3.4 & 13.5 & 3.37 & 0.05 & 1.48 \\
Purbanchal University & 3.2 & 3.3 & 3.1 & 2.8 & 12.4 & 3.10 & 0.22 & 7.10 \\
Nepal Sanskrit University & 3.6 & 3.5 & 3.2 & 3.5 & 13.8 & 3.45 & 0.17 & 4.93 \\
Pokhara University & 3.2 & 3.3 & 3.1 & 2.9 & 12.5 & 3.16 & 0.17 & 5.38 \\
\hline
\end{tabular}

Effectiveness of Higher Education from Students Perspectives has ranged between $3.1(\mathrm{PbU})$ and $3.45(\mathrm{NSU})$. All most all the students of the universities have been satisfied with the performance of their faculties, with the contents of the subject, with the evaluation system and infrastructure \& the policies of the universities. This has been supported by the values more than 3 in all the universities except in Purbanchal and Pokhara Universities in which values were below 3 in case of infrastructure and the policies of the universities.

The overall effectiveness of higher education in Nepal from students' perspectives has been satisfactory. In all the universities, the value of standard deviation has been below 1 and coefficient of variation has been $1.48 \%$ to $8.96 \%$. This clearly indicates the mean is dependable.

\subsubsection{Analysis of the Effectiveness of Higher Education in Nepal from Employers Perspectives}

How motivated and satisfied are the employers of different organizations with the higher education in Nepal? This question is very important for assessing 
the effectiveness of higher education in Nepal from employers' perspectives. In this regard three questions have been asked to the employers i.e. "How much" a. capable do they find the graduates from different universities of Nepal (CG), b. committed/motivated are the graduates in their jobs (CM) and c. they are impressed by the graduates performances (IP)

\begin{tabular}{lccccccc}
\hline Name of the Banks & CG & CM & IP & Total & Mean & S. D. & C. V. \\
\hline Banking Sectors & 3.3 & 3.4 & 3.2 & 9.9 & 3.30 & 0.10 & 3.03 \\
Education Sectors & 3.2 & 3.4 & 3.3 & 9.9 & 3.30 & 0.10 & 3.03 \\
Medical Sectors & 4.5 & 3.8 & 3.9 & 12.2 & 4.07 & 0.38 & 9.34 \\
Engineering Sectors & 4.2 & 3.7 & 3.8 & 11.7 & 3.90 & 0.26 & 6.67 \\
Miscellaneous Sectors & 2.8 & 3.2 & 3.0 & 9.0 & 3.00 & 0.20 & 6.67 \\
\hline
\end{tabular}

Effectiveness of Higher Education from Employers Perspectives has ranged between 3.0 (Misc. Sectors) and 4.07 (Medical Sectors). All most all the employers from different organizations have been satisfied with the performance of their employees (students from different universities). They have been impressed from the performance of the Nepalese students and they found that they are capable and committed on their job.

The overall effectiveness of higher education in Nepal from employers' perspectives has been satisfactory. In all the universities, the value of standard deviation has been below 1 and coefficient of variation has been $3.03 \%$ to $9.34 \%$. This clearly indicates the representative nature of the mean calculated.

\section{Conclusions}

Higher education is one of the most important factors for the overall progress of the country. Higher education develops human resource in a country that will take care of other remaining resources in the country. It is very important for the development of the nation. It has lately been realized that a nation can develop and prosper even without other resources if it has competent and educated manpower.

Tribhuvan University has taken major responsibilities regarding number of students and campuses in the country i.e. about 80 percent of total students and campuses have been in Tribhuvan University alone. Result shows that only about 20 percent students have been passed out from the colleges every year.

Majority of the faculties of the universities have satisfied with the performance of their students, with the contents of the subjects matter, with the evaluation system and infrastructure $\&$ the policies of the universities.

From students' point of view, majority of them have been satisfied with the performance of their faculties, with the contents of the subject matter, with the evaluation system and infrastructure \& the policies of the universities.

Similarly, almost all the employers from different organizations have been satisfied with the performance of their employees (students from different universities). They have been impressed with the performance of the Nepalese students and they found that they are capable and committed on their job.

Hence, it is concluded that higher education in Nepal has been effective to satisfy the different stakeholder as well as to meet the objectives for which it was envisioned. 


\section{Recommendations}

Though the effectiveness of higher education in Nepal has been satisfactory from the different stake holders' point of view, there is the need for improving the quality of higher education at every stage so that a proper foundation can be laid for advanced study in engineering, management, medical, education, agriculture and other areas which are most closely allied to the national economic development and reconstruction of the nation as a whole. A main point to be considered by educational planner is the adaptation of a multidimensional, flexible, and dynamic education system, which serves people according to their ability and is responsive to their economic, social political and cultural needs. The higher education system should be flexible enough to offer a variety of courses, formal and non formal, full time and part time, correspondence and media based to fit every individual as well as the economic needs of the country.

The following suggestions are recommended for the improvement of the quality of higher education:

- Faculty development program should be implemented to improve the quality of the faculties

- Infrastructures facilities should be improved by identifying and generating internal and external funding

- Evaluation systems should be upgrade timely according to international standard

- $\quad$ Curriculum and course contents should be timely and properly updated with current scenarios and it should contain relevant issues

- Teaching methodology and pedagogy should be changed timely. Focus should be given to implement IT.

- $\quad$ Proper collaboration should be developed between academic institutions and employers for job placements

- Government should formulate policies to attract private sectors for investing in higher education. Government spending in higher education is low - about $7 \%$ of public expenditures in education.

\section{References}

Aryal, M.P, (2005), Higher and Higher Secondary Education in Nepal,.Kathmandu, Nepal

Bhattarai, K., P. (2014). Higher Education in Nepal: Truth And Challenges. Accessed on http:// civilinitiative.org/254/\#sthash.BWEwa6zZ.dpuf 07/06/2015

CEDA (2003), A Study on Effectiveness of Investment in Higher Education Project. Kathmandu Nepal Central Bureau of Statistics. (2016). Nepal in Figure, 2016. Thapathali, Kathmandu: Nepal Planning Commission Secretariat.

Centre for Economic Development and Administration. (2007). Financing the Higher Education in Nepal. Kritipur, Kathmandu: Centre for Economic Development and Administration, Tribhuvan University.

Higher Education Reform Project. (2014). Environmental Management Framework for Higher Education Reform Project Nepal. Kathmandu: Higher Education Reform Project.

KU, (2005), Kathmandu University, Quality Education for Leadership, Kavre, Nepal.

KU, (2005), Kathmandu University, Progress Report (2015/16)

Ministry of Finance. (2016). Budget speech of fiscal year 2015/2016. Kathmandu: Government of Nepal, Ministry of Finance. 
Pravaha Journal-2018

MoF, (2016), Economic Survey 2015/16, Ministry of Finance, Kathmandu, Nepal.

NSU, (2016), Nepal Sanskrit University, Annual Report, (2015/16) (Dang, Nepal).

PU, (2016), Pokhara University, Progress Report of 2015/16

Purbanchal University (2016), Progress Report of 2015/16

Second Higher Education Project. (2007). A Brochure, Second Higher Education Project 2007- 2014. Sanothimi, Bhaktapur: University Grants Commission.

Simkhada, P. \& Teijlingen, V. (2010). Higher Education in Nepal: Several Challenges Ahead. Dispora 2010, 3(1), 44-47. 56

TU, (2016), Tribhuvan University, Annual Report FY 2015/16 Planning Division, TU Kathmandu, Nepal

UGC, (2016), University Grants Commission, Annual Report, (2015/16) (Kathmandu, Nepal),Wolf, K \& Pant, P.R.(2005). Social Science Research and Thesis writing. Buddha Academic Publishers and Distributors Pvt. Ltd. Nepal

Zechalin, L., (2010). Higher Education- Management, Leadership and Governance. Strategic Planning on Higher Education, 256-263. Elsvier Publication. 